\title{
CLIL APPLIED TO PRE-UNIVERSITY CHEMISTRY TEACHING IN ENGLISH: BULGARIA AS A CASE-STUDY
}

\author{
Lino Bianco ${ }^{1,2 *}$, ORCID: 0000-0001-8779-2351, \\ Irina Andonova ${ }^{3}$, ORCID: 0000-0001-5595-6868, \\ Anton Buhagiar ${ }^{4}$ \\ ${ }^{1}$ University of Malta, MSD 2080 Msida, Malta \\ 2University of Architecture, Civil Engineering and Geodesy, 1, Hristo Smirnenski Blvd, 1046 Sofia, Bulgaria \\ ${ }^{3}$ Sofia University St. Kliment Ohridski, 1, James Bourchier Blvd, 1164 Sofia, Bulgaria \\ ${ }^{4}$ Formerly of the University of Malta, MSD 2080 Msida, Malta; deceased. \\ *Corresponding author: Lino Bianco, Lino.bianco@um.edu.mt
}

Received: 06. 23. 2021

Accepted: 08. 02. 2021

\begin{abstract}
Content and Language Integrated Learning (CLIL) is bilingual education whereby students do not only study a second language, in addition to their native tongue, but learn a school subject in that foreign language. This study is based on the teaching of chemistry in English to Grade 9 students in the Republic of Bulgaria. Correlation exists between the performance of students in chemistry taught in English with their performance in English in Grade 8 and Grade 9. There is also a correlation between their performance and gender and regarding the second language chosen. In fact, students who opted for Russian and Spanish fared better than those who opted for German and French. More laboratory experiments at school, lessons incorporating interesting games, and stimulating interactive projects were recommended by students as useful tools to improve their scientific literacy.
\end{abstract}

Keywords: CLIL, English as a foreign language, chemistry education, bilingual education, scientific literacy.

Abstract. Conținutul și învățarea integrată a limbilor străine (CLIL) este o educație bilingvă prin care elevii nu numai că studiază o a doua limbă, pe lângă limba lor maternă, dar învață o disciplină școlară în acea limbă străină. Acest studiu se bazează pe predarea chimiei în limba engleză elevilor de clasa a 9-a din Republica Bulgaria. Există o corelație între performanța elevilor în chimie predată în limba engleză cu performanța lor în limba engleză în clasa a 8-a și clasa a 9-a. Există, de asemenea, o corelație între performanța și sexul acestora și în ceea ce privește a doua limbă aleasă. De fapt, studenții care au optat pentru rusă și spaniolă s-au descurcat mai bine decât cei care au optat pentru germană și franceză. Mai multe experimente de laborator la școală, lecții care încorporează jocuri interesante și stimularea proiectelor interactive au fost recomandate de elevi ca instrumente utile pentru îmbunătățirea alfabetizării lor științifice.

Cuvinte cheie: CLIL, engleza ca limbă străină, educație în chimie, educație bilingvă, alfabetizare științifică. 


\section{Introduction}

Coyle et al. [1] define Content and Language Integrated Learning (CLIL) as “... a dualfocused educational approach in which an additional language is used for the learning and teaching of both content and language. That is, in the teaching and learning process, there is a focus not only on content, and not only on language. Each is interwoven, even if the emphasis is greater on one or the other at a given time".

Mehisto et al. [2] note that "CLIL is an approach which involves the development of social, cultural, cognitive, linguistic, academic and other learning skills which in turn facilitate achievements in both content and language". CLIL refers to the teaching of subjects such as chemistry, biology, history, and mathematics to students through a foreign language [3]. Its communicative element may be illustrated by the following expression, used in the literature of the British Council: "using language to learn whilst learning to use language" [4], or, as is stated in a European Commission document used freely by Rizzo [5], "Within CLIL, language is used as a medium for learning content, and the content is used in turn as a resource for learning languages" [6]. The promotion of scientific literacy through renewed interest in teaching science to students has been on the agenda of the Commission for over a decade [7]. This must be read in the context of a development trajectory of CLIL which dates back to the early 1990s, a theme studied by Marsh [8]. The Eurydice survey concluded that by 2006 CLIL was being used in 30 European countries [9].

\section{Bilingual education in Bulgaria}

The Government of Bulgaria, known as the People's Republic of Bulgaria from 1946 until the foundation of the Republic of Bulgaria in 1991, has always laid emphasis on the study of the English language. After the end of the Second World War, the study of English was made compulsory in many primary and secondary schools and the number of students studying English increased rapidly [10]. During Communist rule the country had an extremely literate public [11]. Pavel Patev, one of the founders of intensive bilingual training in Bulgaria, maintained that language is not only a subject of study but also a means of learning content such as chemistry, biology and history [12]. The purpose of language training should not be limited to the development of communicative competence, but should also cover cognitive improvement. Higher education in chemistry in Bulgaria during this period is broadly covered in a comparative study undertaken by Wotiz [13].

Bilingual education in Bulgaria is over a century old, but attracted greater attention from the 1960s onwards with the emergence of extended language learning schools where some academic subjects were taught through a second language, preferably by teachers who were native speakers-specialists of the chosen second language. Despite this extensive history of bilingual education, there are still significant problems relating to teaching subjects in English. The following issues were identified by Danailov and Tafrova-Grigorova [14]: (i) the absence of an official curriculum that unites the outcomes of both the subject being taught and the language used for teaching it; (ii) a lack of appropriate teaching materials, and (iii) a shortage of well-prepared teachers to develop teaching material for a given school subject in a foreign language. This study looks at the performance of students studying chemistry in English over a two-year period and evaluates their feedback on how such teaching can be improved.

As had happened in other parts of Europe, at the turn of the new millennium CLIL practice spread rapidly throughout Bulgaria [15]. Teaching programmes in education in the Republic of Bulgaria must comply with the relevant State Educational Standards issued by 
the Ministry of Education and Science. These are based on the official curriculum of the Ministry [16]. They consist of a schedule for teaching the discipline for a given scholastic year. The schedule includes the number of contact hours per week, the relative topics delivered, and the expected outcomes in terms of students' knowledge, practical skills and attitudes. Furthermore, it outlines the methodology which can be utilised for the delivery of the relevant topics. With respect to each academic subject, it is up to the teacher to develop the methodology but it is imperative that the specified contact hours are utilised to cover all the topics in order to satisfy the learning outcomes established by the Ministry.

Unique for the Bulgarian model of Extended Language Learning in Language Schools is that in their first year at such schools, namely Grade 8, students study the target foreign language for 18 hours per week / 648 hours per year together with their mother tongue, mathematics, art, music and physical education. This contributes to a deeper comprehension of the foreign language which in turn empowers the students in pre-tertiary education, where they study subjects such as chemistry, biology, history and geography in the target foreign language. The contact hours for teaching chemistry in English at Grade 9 are 90 hours per scholastic year of 36 weeks, that is 2.5 hours per week. These are broken down according to the following percentage weighting given by the Ministry - lessons in class: $56 \%$, seminars/discussions/projects/laboratory work: $25 \%$, overall assessment: $8 \%$, and revision and summaries: $11 \%$.

During the course of the scholastic year, students have to undergo regular tests, 2 to 3 per term. The idea underlying these tests is that they should serve as a continuous assessment of the student's comprehension and commitment to the study of the discipline. Each test, undertaken during a lesson of 40-minutes' duration, covers the chapter/s taught and may include a number of topics. The aim of the first test, which is held at the commencement of the scholastic year, is to gauge the student's initial knowledge of the subject. During the first term students are given two further tests: one in the middle and the other at the end. During the second term, they have another two tests together with a final group project which is not compulsory. Assessment also includes the student's participation in class, project presentation, and so on. Such assessments are regulated by the Ministry of Education and Science [17]. Under this regulation, each student's assessment consists of $40 \%$ for the written or oral examinations, $30 \%$ for tests and $30 \%$ for seminars/discussions/projects/laboratory work.

The ordinance regulating general education preparation delineates the requirements for the learning outcomes of foreign languages and all other subjects taught in Bulgarian secondary schools [18]. These outcomes provide a level playing field for an integrated introduction and development of listening, speaking, reading and writing, the core of the language competencies required to develop students' life skills. Furthermore, such requirements must include interaction between foreign language courses and other educational subjects. These requirements describe each level that the students are expected to achieve upon completion of a level corresponding to A1 - B2 proficiency in terms of the Common European Framework of Reference for Languages (CEFRL).

This paper aims to address the following research questions: (i) how does the performance of students taught chemistry in English relate to their performance in English (the second foreign language taught at school)? (ii) are there any gender related differences relating to (1) above? and (iii) what are the opinion/s and/or suggestion/s of students regarding the improvement of the teaching of chemistry in English? 


\section{Methodology}

The study is based on 32 Secondary Language School 'St Kliment Ohridski', Sofia. The foreign language which this school targets is English. Consequently, this school is one of the largest schools in Bulgaria and almost all the students who complete their education at this institution proceed to tertiary education. The academic staff are all university educated and, on average, have two decades of experience. The staff aim to achieve the holistic formation of the students and the school regularly participates in student exchanges with other schools within and outside Europe. A comment by the parents of one of the students in response to why they chose this school over others is a testimony to the standing of the institution: "We were attracted to the high requirements and criteria imposed by tradition, as well as the ability to learn first-class English" [19]. Based on its extended language learning programmes, this school was considered an innovative institution in Bulgaria in the scholastic year 2018/19.

The survey sample is made up of students studying chemistry taught in English who were in Grade 10 at the commencement of the scholastic year 2019/20. Students begin studying chemistry in English in Grade 9 (average age 14 to 15 years). With regard to the first research question, the final scores of their annual results in chemistry and English in Grade 9, and English in Grade 8 were evaluated. With respect to the third research question, Grade 10 students were asked to list their opinion/s and suggestion/s on how to improve the teaching of chemistry in English. The individual responses of the participants who willingly agreed to take part were kept anonymous to ensure confidentiality.

The sample for this study, undertaken in the form of a census, was 156 students in total (male: $N=74,47.4 \%$; female: $N=82,52.6 \%$ ). Each student was attending one out of six classes - A, B, C, D, E and F - where German is taught in Classes A and B, Spanish in C and D, French in E and Russian in F. In Grade 8, should they be promoted to Grade 9, students are required to choose a second foreign language besides English. The analysis looked at the following five variables (i) the gender of the student (female or male), (ii) classes in Grade 9 - A, B, C, D, E, F, (iii) score attained in chemistry in Grade 9, (iv) score attained in English in Grade 9, and (v) score attained in English in Grade 8.

\section{Results}

The students were distributed uniformly into the six classes as evidenced by the crosstabulation of class with gender, and the corresponding non-significant Chi-squared (Chisquared $=1.826 ; d f=5 ; p=0.886)($ Table 1$)$.

Table 1

Cross-tabulation: class versus gender

\begin{tabular}{ccccc}
\hline Class & Second foreign language & Female & Male & Total \\
\hline A & German & 15 & 11 & 26 \\
B & German & 11 & 14 & 25 \\
C & Spanish & 13 & 14 & 27 \\
D & Spanish & 13 & 12 & 25 \\
E & French & 14 & 12 & 26 \\
F & Russian & 16 & 11 & 27 \\
Total & & 82 & 74 & 156 \\
\hline
\end{tabular}


The scoring system for exams in Bulgaria is as follows: 2 (poor), 3 (satisfactory), 4 (good), 5 (very good) and 6 (excellent). Thus, the marks attained in Chemistry_9, English_9 and English_8 are integer scores between 2 and 6, both inclusive, with 2 being the lowest mark and 6 the highest. The distribution of these scores is given in Table 2. For all scores, the mean and median are in the region of 5.1 and the standard deviation is approximately 0.8 .

Table 2

Distribution of scores

\begin{tabular}{ccccc}
\hline Parameter & Percentiles & Chemistry_9 & English_9 & English_8 \\
\hline $\mathrm{N}$ & & 156 valid; & 156 valid; & 156 valid; \\
Mean & & 0 missing & 0 missing & 0 missing \\
Std. Deviation & 5.190 & 5.100 & 5.090 \\
Minimum & 0.825 & 0.821 & 0.822 \\
Maximum & 3 & 3 & 3 \\
& 25 & 6 & 6 & 6 \\
& 50 & 5 & 4 & 5 \\
& 75 & 5 & 5 & 5 \\
\hline
\end{tabular}

The two-way analysis of variance of Chemistry_9 on gender and class determined whether the score in chemistry depended on gender and class. The two-way ANOVA table (Table 3$)$ shows that both gender $(p=0.009)$ and class $(p=0.000)$ were significant, as was their interaction $(p=0.033)$. The $95 \%$ confidence intervals for gender are given in Table 4 . The mean for females is significantly higher than that for males $(p=0.009)$. For the different classes, the confidence intervals for Chemistry_9 are given in Table 5.

Table 3

Tests of Between-Subjects Effects

\begin{tabular}{cccccc}
\hline Source & Type III Sum of Squares & df & $\begin{array}{c}\text { Mean } \\
\text { Square }\end{array}$ & $F$ & Sig. \\
\hline Corrected Model & 26.165 & 11 & 2.379 & 4.311 & 0.000 \\
Intercept & 4101.611 & 1 & 4101.611 & 7434.548 & 0.000 \\
gender & 3.903 & 1 & 3.903 & 7.074 & 0.009 \\
class & 14.878 & 5 & 2.976 & 5.394 & 0.000 \\
gender* ${ }^{*}$ class & 6.929 & 5 & 1.386 & 2.512 & 0.033 \\
Error & 79.444 & 144 & 0.552 & & \\
Total & 4301.000 & 156 & & & \\
Corrected Total & 105.609 & 155 & & & \\
\hline
\end{tabular}

Table 4

\section{Confidence intervals by gender for dependent variable Chemistry_9}

\begin{tabular}{cccc}
\hline Gender & Mean & Std. Error & $\begin{array}{c}\text { 95\% Confidence Interval } \\
\text { (lower bound / upper bound) }\end{array}$ \\
\hline Female & 5.325 & 0.083 & $5.161 / 5.488$ \\
Male & 5.006 & 0.087 & $4.834 / 5.177$ \\
\hline
\end{tabular}


Confidence intervals by different classes for dependent variable Chemistry_9

\begin{tabular}{cccc}
\hline Class & Mean & Std. Error & $\begin{array}{c}\text { 95\% Confidence Interval } \\
\text { (lower bound / upper bound) }\end{array}$ \\
\hline A & 5.091 & 0.147 & $4.800 / 5.382$ \\
B & 4.792 & 0.150 & $4.496 / 5.088$ \\
C & 5.445 & 0.143 & $5.162 / 5.728$ \\
D & 5.625 & 0.149 & $5.331 / 5.919$ \\
E & 4.786 & 0.146 & $4.497 / 5.074$ \\
F & 5.253 & 0.145 & $4.965 / 5.540$ \\
\hline
\end{tabular}

ANOVA also shows an effect due to class $(p=0.000)$. The Student-Newman-Keuls posthoc test shows that Class $B$ and Class $E$, with means near 4.8 , had significantly smaller means than Classes F, C and D, whose means were > 5.3 (used harmonic mean sample size $=25.974$; the group sizes were unequal; and the harmonic mean of the group sizes was used whereby Type I error levels were not guaranteed; and alpha $=0.05$ ). The homogenous subsets are given in Table 6.

Table 6

Homogeneous subsets with respect to Chemistry_9

\begin{tabular}{ccccc}
\hline Class & N & Subset 1 & Subset 2 & Subset 3 \\
\hline B & 25 & 4.80 & & \\
E & 26 & 4.81 & & \\
A & 26 & 5.08 & 5.08 & \\
F & 27 & 5.33 & 5.33 & 5.33 \\
C & 27 & & 5.44 & 5.44 \\
D & 25 & & & 5.64 \\
Sig. & & 0.052 & 0.179 & 0.300 \\
\hline
\end{tabular}

The confidence intervals for the categories by gender and class and a plot of the means of each category are given in Table 7. The interaction between gender and class is significant (from ANOVA, $p=0.033$ ) as evidenced by the fact that for Classes A and B, the mean for males is higher than that for females, whereas in the other classes, females have a higher mean than males. The estimated marginal means of Chemistry_9 are given in Figure 1.

Table 7

Confidence intervals for the gender*class categories with respect to Chemistry_9

\begin{tabular}{ccccc}
\hline Gender & Class & Mean & Std. Error & $\begin{array}{c}\text { 95\% Confidence Interval } \\
\text { (lower bound / upper bound) }\end{array}$ \\
\hline Female & A & 5.000 & 0.192 & $4.621 / 5.379$ \\
Female & B & 4.727 & 0.224 & $4.285 / 5.170$ \\
Female & C & 5.462 & 0.206 & $5.054 / 5.869$ \\
Female & D & 6.000 & 0.206 & $5.593 / 6.407$ \\
Female & E & 5.071 & 0.199 & $4.679 / 5.464$ \\
Female & F & 5.687 & 0.186 & $5.320 / 6.055$ \\
\hline
\end{tabular}


Continuation Table 7

\begin{tabular}{lllll}
\hline Male & A & 5.182 & 0.224 & $4.739 / 5.624$ \\
Male & B & 4.857 & 0.199 & $4.465 / 5.250$ \\
Male & C & 5.429 & 0.199 & $5.036 / 5.821$ \\
Male & D & 5.250 & 0.214 & $4.826 / 5.674$ \\
Male & E & 4.500 & 0.214 & $4.076 / 4.924$ \\
Male & F & 4.818 & 0.224 & $4.376 / 5.261$ \\
\hline
\end{tabular}

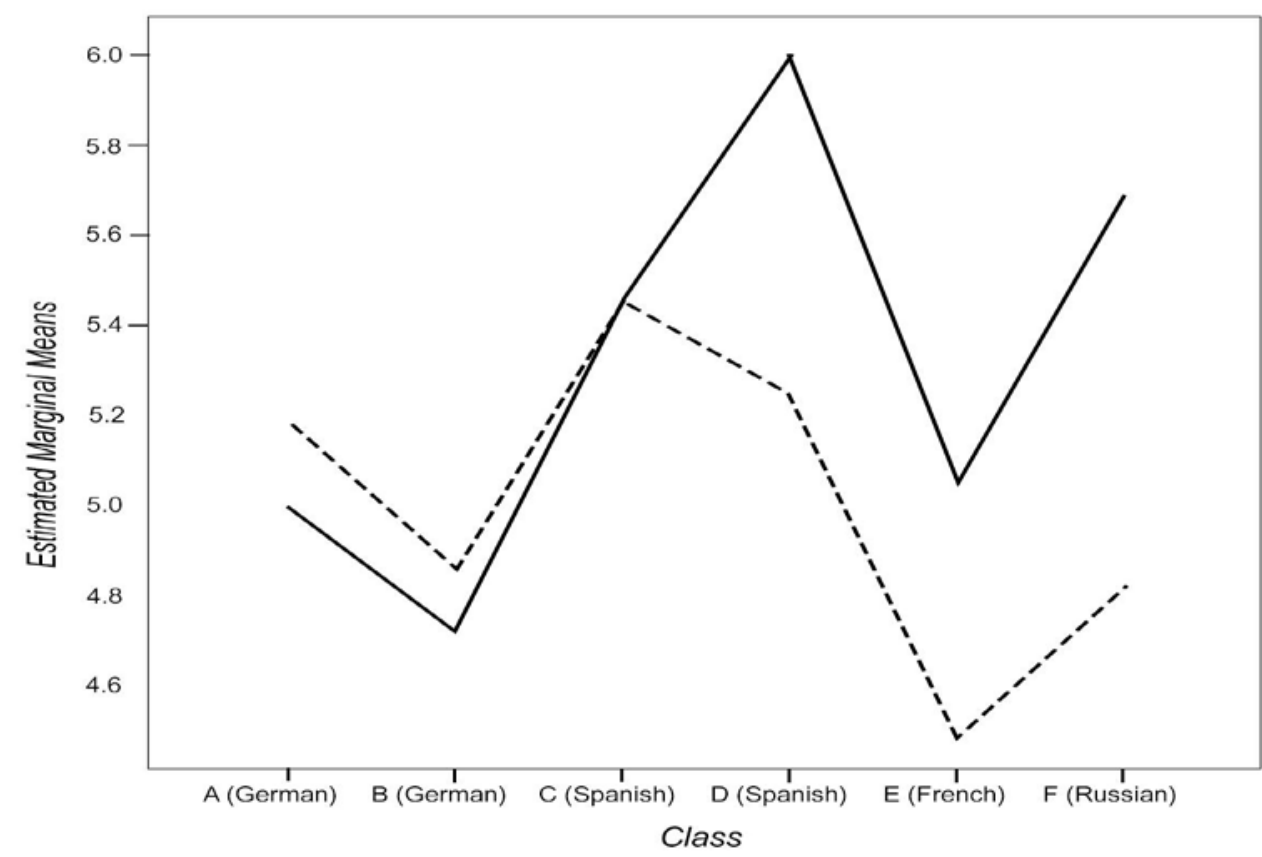

Gender:

Female

-- Male

Figure 1. Estimated marginal means of Chemistry_9.

With respect to the students' achievement in chemistry and English exams, the three scores have appreciable correlation between them (Table 8); all correlations are significant at the 0.01 level. Stepwise regression of Chemistry_9 on English_9, Chemistry_8 and gender leads to regression models Model 1 and Model 2 (Table 9) which are defined as follows:

Model $1=1.518+0.719^{*}$ English_9; and

Model $2=1.059+0.634^{*}$ English_9 $+0.175^{*}$ English_8 .

Table 8

\section{Correlation between scores}

\begin{tabular}{ccccc}
\hline & Pearson & Spearman & Significance & N \\
\hline Chemistry_9 with English_9 & 0.715 & 0.737 & 0.000 & 156 \\
Chemistry_9 with English_8 & 0.479 & 0.487 & 0.000 & 156 \\
English_9 with English_8 & 0.484 & 0.484 & 0.000 & 156 \\
\hline
\end{tabular}

Table 9

Regression models

Model 1

$(1.518+$

$0.719 *$ English_9)

$\begin{array}{ccc}\text { St Err of Coefficient } & (0.293) & (0.057) \\ \text { Significance } & 0.000 & 0.000 \\ \text { Change in R-Squared } & & 0.51\end{array}$

Model 2

$\left(1.059+0.634^{*}\right.$ English_9 + $0.175^{*}$ English_8)

(0.331) (0.063) (0.063)

$\begin{array}{lll}0.002 & 0.000 & 0.006\end{array}$

$0.51 \quad 0.02$


Model 1 would be preferable, since entering English_8 in the model only increases RSquared by $2 \%$. On the basis of Model 1 , in Grade 9, the score in chemistry can be predicted from the score in English. With respect to the students' opinion/s on how to improve the teaching of chemistry in English, only $12 \%(N=15)$ of the participants out of the 142 valid submissions had opinions and/or suggestions on how to improve the teaching of chemistry in English. The suggestions included:

1. lessons in Bulgarian, especially when complicated scientific concepts and terms are involved;

2. the need for experiments at school;

3. lessons (inside and outside school premises) based on interesting games; and

4. more interactive projects centred around interesting topics.

\section{Discussion}

Teaching Chemistry in English has its peculiarities. [20] noted that chemistry, as a science, has its own language: "Science is, in itself, a language and each different science (biology, physics, chemistry) is a separate language". Kelly [21] argued that "If chemistry is a language as well as a body of content, then it needs to be taught as a language as well as a body of content. So, what is the language of chemistry?" He defined three areas of language for any classroom context: subject-specific language, general academic language, and peripheral language. Therefore, each subject teacher should develop language awareness in order to meet the students' needs. This highlights the problem of the teacher's language acquisition.

This paper investigated the performance of students studying chemistry in English in Grade 9. There were cases where students excelled in scientific English more than in English language proficiency. Although this research indicated that students who performed well in chemistry taught in English performed well in both English at Grade 9 and English at Grade 8, students whose second foreign language is German or French performed less well than those taking Spanish or Russian. This conclusion was drawn after applying the StudentNewman-Keuls post-hoc test on homogeneous subsets with respect to the performance of students in chemistry taught in English at Grade 9. Tests of Between-Subjects Effects indicated correlations between the performance of students taught chemistry in English at Grade 9 and gender and class for a given second foreign language. The mean for females was higher than that for males. Furthermore, students who opted for Spanish and Russian performed better than the students who opted for German and French as a second language. Applying Pearson and Spearman Rho, the correlations for (i) the score in chemistry taught in English at Grade 9 with English at Grade 9 and (ii) the score in chemistry taught in English at Grade 9 with English at Grade 8, proved to be similar.

"Hands-on tasks in CLIL Chemistry lessons ... serve as sites for using and learning subject-specific language, conceptualized as both special concepts and terminology as well as specific-subject ways of constructing meaning" [22]. Bulgarian students studying chemistry in English are keen to experience alternative forms of classroom practice [23]. This research reinforces this finding. This illustrates the approach to learning languages in contemporary Bulgarian schools, which is based on a communicative approach. Communication, one of the four essential elements of CLIL identified by Coyle [24], is a basic competence that students should acquire as per the National Educational Standards. Understanding the language through an active, practical consciousness as an important medium for communication is at 
the core of extended language learning. Participants in this study emphasised the need for more hands-on ways of studying, ranging from more laboratory work to more interactive, stimulating practical chemistry projects to improve their scientific literacy. They also suggested that complicated scientific concepts and terms should be explained in the native tongue. This tallies with recent research on pre-tertiary education which found that understanding the content of chemistry lessons was indicated by students as the most challenging task [25]. This has a bearing on the students' approaches to learning chemistry and on their levels of achievement during their first year of study at university [26].

Since the early 1990s, CLIL has become widely recognised for its effectiveness in promoting the teaching of a foreign language [27]. At present, language teachers are moving to content-based instruction - notably through either CLIL or English-Medium Instruction to teach English. As such approaches are becoming popular at a global level, it is imperative to comprehend how these changes in pedagogic methodologies have affected student outcomes.

\section{Conclusions}

This study was based on the teaching of chemistry in English to Grade 9 students in a secondary school in Bulgaria. The following specific conclusions were drawn:

1. The performance of teaching chemistry in English in Grade 9 is highly correlated with the performance of the students in English. In fact, a regression equation can be derived between the scores obtained in the two disciplines;

2. The scores in chemistry also depend on gender and on the second foreign language chosen - students opting for Russian and Spanish fared better than those opting for German and French; and

3. The pattern noted in (2) above is present also in students' English scores in both Grade 9 and Grade 8. For this reason, gender does not enter into the stepwise regression referred to in (1) above.

CLIL teachers are responsible "to make the language of their subjects visible and approachable to students" [22]. The need for further pedagogical courses in bilingual teaching and the limited quality of textbooks and supplementary texts have been identified by teachers of chemistry in English at Bulgarian high schools as key limitations that constrain their ability to carry out their work [14]. Science teachers agree that scientific literacy would improve if the existing curriculum were amended to engage students in "more real life knowledge, experimental work and key competences and thus ... enhance greater scientific literacy of students" [28]. Bulgarian students studying chemistry in English are keen to experience alternative forms of classroom practice [23]. Participants suggested more chemistry experiments in school laboratories, stimulating lessons (inside and outside school premises) based on evocative games, and more interactive projects addressing interesting topics. These will supplement and reinforce more effectively the communicative approach adopted in learning languages in contemporary Bulgarian schools.

Acknowledgments: Irina Andonova would like to thank her academic supervisor, Prof. Dr Elena Boyadjieva, Head of the Laboratory of Chemical Education and History and Philosophy of Chemistry, Faculty of Chemistry and Pharmacy, Sofia University St Kliment Ohridski. She would like also to thank Nelly Kostova, Head of 32 Secondary Language School 'St Kliment Ohridski' (Sofia), the staff and the students who participated in this study. 
Lino Bianco would like to thank the late Prof. Dr Anton Buhagiar, co-author of this paper, who passed away a few days after this manuscript was completed for submission. He was a true gentleman, academic, mentor and colleague whose legacy will surely endure. He was a brilliant mind, humble and generous with his encouragement and advice. His calm demeanour and altruism were an inspiration to all who worked with him. He was loved and respected, and he will be missed; many of us will remember his caring smile and the wealth of academic support he gave to colleagues, as well as past and present students. Thank you, Anton, for your magnanimous friendship. I never foresaw that our paper would be your last work to get published.

\section{References}

1. Coyle D., Hood P. and Marsh D. Content and Language Integrated Learning. Cambridge: Cambridge University Press, 2010.

2. Mehisto P., Marsh D. and Frigols M. Uncovering CLIL: Content and Language Integrated Learning in Bilingual and Multilingual Education. Oxford: Macmillan, 2008.

3. Marsh D. and Marsland B. CLIL Initiatives for the Millennium: Report of the CEILINK Think-Tank. Finland: University of Jyväskylä, 1999.

4. British Council. CLIL: A lesson framework. 2020. [accessed 07.02.2020]. Available: https://www.teachingenglish.org.uk/article/clil-a-lesson-framework

5. Rizzo R. The role of conversation in Higher Education. A view on differentiation in a CLIL based approach. In: Filice S., ed., CLIL in Progress: From theoretical issues to classroom practice. Varazze: PM Edizioni, 2016, pp. $51-65$.

6. European Commission. European language policy and CLIL: A selection of EU-funded projects. Brussels: European Commission, 2006.

7. European Commission. Science Education NOW: A renewed Pedagogy for the Future of Europe. Luxembourg: Office for Official Publications of the European Communities, 2007.

8. Marsh D. Content and Language Integrated Learning (CLIL): A development trajectory. Córdoba: University of Córdoba, 2012.

9. García Guerrero P. The Pendulum Effect in CLIL Research: Lessons Learned and Ways Forward. Master's Dissertation. Andalucía (Spain): University of Jaén, 2015. [accessed 14.01.2020]. Available: http://tauja.ujaen.es/bitstream/10953.1/2189/1/GARCA_ 1.PDF

10. Rankova M. The Teaching of English in Bulgaria. In: ELT Journal, 1959, 13 (2), pp. 72 - 77.

11. Garkov V. N. Chemical Education in Bulgaria. In: Journal of Chemical Education, 1999, 76 (8), 1083, https://doi.org/10.1021/ed076p1083

12. Patev P. L. Intensive study of French: Theory and practice. Sofia: Public Education, 1982 (in Bulgarian).

13. Wotiz J. H. Higher education in chemistry in Bulgaria, Hungary, Poland, Romania, and Yugoslavia. In: Journal of Chemical Education, 1973, 50 (8), 520, https://doi.org/10.1021/ed050p520

14. Danailov B. and Tafrova-Grigorova, A. (2014). Problems of Chemistry education in English according to Bulgarian teachers. In: Journal of Sofia University for Educational Research, 2014, 4, pp. 71 - 76 (in Bulgarian).

15. Pérez Cañado M. L. Introduction. In: Revista de Lenguas para Fines Específicos, 2013, 19, pp. 15 - 30.

16. Ordinance No. 4 of November 30, 2015 on the Curriculum. Ministry of Education and Science [of the Republic of Bulgaria], 2015. [accessed on 11.01.2020]. Available: https://www.mon.bg/bg/59

17. Ordinance No. 11 of September 1, 2016 on the Evaluation of the Results of the Students' Education. Ministry of Education and Science [of the Republic of Bulgaria], (2016). [accessed on 11.01.2020]. Available: https://www.mon.bg/bg/59

18. Ordinance No. 5 of November 30, 2015 on General Education Preparation. Ministry of Education and Science [of the Republic of Bulgaria], 2015. [accessed on 11.01.2020]. Available: https://www.mon.bg/bg/59

19.32 St Kliment Ohridski Secondary School. 2020. [online]. [accessed 07.02.2020]. Available: https://www.school32.com/index_bg.html

20. Carrasquillo A. and Rodriguez V. Language Minority Students in the Mainstream Classroom. Bristol: Multilingual Matters, 2002.

21. Kelly K. A New Challenge for Chemistry Education. In: Chemistry International, 2010, 32 (5), pp. 4 - 7. https://doi.org/10.1515/ci.2010.32.5.4 
22. Nikula T. Hands-on tasks in CLIL science classrooms as sites for subject-specific language use and learning. In: System, 2015, 54, pp. 14 - 27, https://doi.org/10.1016/j.system.2015.04.003

23. Bianco L. and Andonova I. Content and Language Integrated Learning applied to teaching chemistry: A case study from Eastern Europe. In: Chemistry, 2020, 29 (3), pp. 283 - 298.

24. Coyle D. Theory and planning for effective classrooms: supporting students in content and language integrated learning contexts. In: Masih, J., ed. Learning through a foreign language. London: Centre for Information on Language Teaching and Research, 1999, pp. 46 - 62.

25. Olić S. and Adamov J. The relationship between learning styles and students' chemistry achievement. In: Macedonian Journal of Chemistry and Chemical Engineering, 2018, 37, pp. 79 - 88, https://doi.org/10.20450/mjcce.2018.1400

26. Olić Ninković S., Adamov J. and Vojinović Ješić L. Relations between learning approaches of chemistry students and their achievement in general chemistry. In: Macedonian Journal of Chemistry and Chemical Engineering, 2019, 38, pp. 293 - 300, https://doi.org/10.20450/mjcce. 2019.1784

27. Cenoz J., Genesse F. and Gorter D. Critical Analysis of CLIL: Taking stock and looking forward. In: Applied Linguistics, 2014, 35, pp. 243 - 262, https://doi.org/10.1093/applin/amt011

28. Tafrova-Grigorova A., Kirova M. and Boyadjieva E. (2011). Science teacher's beliefs about scientific literacy. In: Chemistry, 2011, 20, pp. 507 - 519 (in Bulgarian). 